\title{
【論文】 \\ タンパク質物質拡散現象における広域䋸衝液の影響評価 Evaluation of the Influence of Universal Buffer Solution on Diffusion Phenomena of Protein
}

\author{
小宮敦樹*、円山重直*、守谷修一* \\ Atsuki Komiya, Shigenao Maruyama and Shuichi Moriya
}

\begin{abstract}
これまでの位相シフト技術を改良利用した微小非定常拡散場高精度計測システムを開発し，タンパ ク質の物質拡散現象の高精度観察を行った。広域緩衝液の $\mathrm{pH}$ 值をパラメータとした計測実験を行い, 見かけの物質拡散係数を導出することで，広域緩衝液が拡散現象に及ぼす影響について定性的な評価 を行った。本計測法では非定常拡散場を空間的に高解像度で可視化することができるため，拡散場の 局所計測が可能となり，そこから併せて物質拡散係数の濃度依存性評価も試みた。タンパク質の拡散 現象は緩衝液の $\mathrm{pH}$ 值により大きく変化し，環境が酸に偏ると拡散速度が増加し，特に高濃度ではそ の傾向が顕著になることが定性的に評価された。また濃度依存性が緩衝液 $\mathrm{pH}$ 值の違いによって異な ることも確かめられた。
\end{abstract}

In this paper, the influence of universal buffer on diffusion phenomena of protein was studied. We have developed short-time yet precise observation system of mass diffusion phenomena of protein. The system can produce spatially clear and high resolution concentration distribution image compared with conventional interferometer. In order to investigate the influence of $\mathrm{pH}$ value of the buffer on diffusion phenomena, several $\mathrm{pH}$ values of universal buffer solution were used. Also, to investigate the concentration dependency of pseudo mass diffusion coefficient, solutions over a wide range of concentration were prepared. The experiments were carried out under isothermal condition, and available data were found. The dependency of $\mathrm{pH}$ value of surrounding buffer and that of concentration on diffusion phenomena were discussed.

[Keywords: diffusion coefficient, optical system, proteins, concentration dependency]

\section{1. 緒言}

生体工学分野等において体内での生体高分子（タンパ ク質）の物質輸送過程を解明するには，タンパク質等の 巨大分子の物質拡散係数が必要不可欠となる。特に体内 では強酸性等の極限環境下での物質輸送が存在するため, 環境が拡散現象にどのように影響を及ぼすかについても 解明の必要がある.V. Magueijo らは塩が存在する条件下 での Lysozyme の濾過作用について研究を行い, 塩分濃度 がタンパク質物質輸送過程に影響を及ぼすことを実験的 に確かめている[1]. また，生体を模擬した寒天内や膜内 といった環境下でのタンパク質の物質拡散係数を導出す る実験的研究も数多く行われている[2-5]. しかしながら, これらの測定はいずれも数時間から数日という長時間の 計測が必要であり, 温度, 濃度, $\mathrm{pH}$ 值等が大きく変わっ てくる体内の諸環境を模擬した条件下での物質拡散係数

* 東北大学流体科学研究所、干980-8577 仙台市青葉区片平 2-1-1. Institute of Fluid Science, Tohoku University, 2-1-1 Katahira, Aoba-ku, Sendai 980-8577.

FAX: 022-217-5244 E-mail: komy@pixy.ifs.tohoku.ac.jp
のデータベース構築に効率的な方法ではないといえる. 諸条件下でのデータベース構築のためには，簡易迅速か つ高精度測定が可能な測定法の開発が必要となってくる. これに対し，著者らはこれまでに物質拡散係数の高精 度測定において, 独自に製作した拡散セルを用いて物質 拡散係数の短時間簡易測定技術の確立を行ってきた [6]. 対向流型拡散セルと称するこのセルは拡散場形成時に初 期擾乱を極力抑えることができ，初期濃度分布もステッ プ状に近い状態で与えることが可能となる。これにより 測定に必要とする時間も短縮化されている。しかしなが ら, 対向流型拡散セルでは濃度拡散場を形成する際, 拡 散セル内に試料溶液を連続的に注入する必要があり, 稀 有な物質の物質拡散係数測定には適用できない. 一方, 従来のシェアセル方式を用いた測定技術も確立している が，より少ない濃度差で多くの干渉縞を得るように光路 長を長くしたセルを設計をしたため, 結果として溶液を $0.1 \mathrm{cc}$ 程度必要としている[7]. また, 新たな解析法を用い ることで，より微小量で物質拡散係数の測定が行えるマ イクロ拡散セルの開発も行ってきており, $\mu$ 莳ーダーの 
試料で物質拡散係数が測定可能であることを示してきた [8]. これらの測定では, 光学系を用いることで微小領域 を高精度に計測し，測定時間の短縮化を図っている。さ らに, 既存の位相シフト技術を利用した光学干渉計を改 良することにより，更なる高精度計測が可能な測定系の 構築を行ってきている.

以上の物質拡散係数測定法確立のもと本研究では，比 較的拡散現象が遅いと推測されるタンパク質等, 高価な 試薬の物質拡散係数を少量試料で導出するために，これ までに開発した測定系を改良利用し，体内などの極限環 境下で夕ンパク質物質拡散現象が周囲環境の影響をどの ように受けるか実験的検証を行った。また，一回の計測 で物質拡散係数の濃度依存性を評価する手法についての 検討も行ったので，測定実験の結果と併せて報告する.

\section{2. 実験装置}

\section{1 改良型位相シフト干涉計}

実験装置概略図を Fig. 1 に示す. 装置は干涉計部, CCD カメラおよびコンピュータで構成される画像処理部, 微 小拡散場を形成するセル部に分けられる。

本研究では, Mach-Zehnder 型の干渉計に, 中楯ら[9]が 開発した位相シフト技術を導入している。これまでは Fig. 2(a)に示すように独自に開発した偏光波面分割3CCD メ ラで干渉縞を撮影し，同時に位相の異なる 3 つの干渉縞 を得，そこから位相シフトデータを演算していたが，こ の方式ではカメラ内の各 CCD センサの感度の差異により 演算結果の一部が演算処理時のノイズとして生じてしま う問題があった。

そこで新たな方法として，Fig.2(b)に示すような単独の

Mach-Zehnder Interferometer

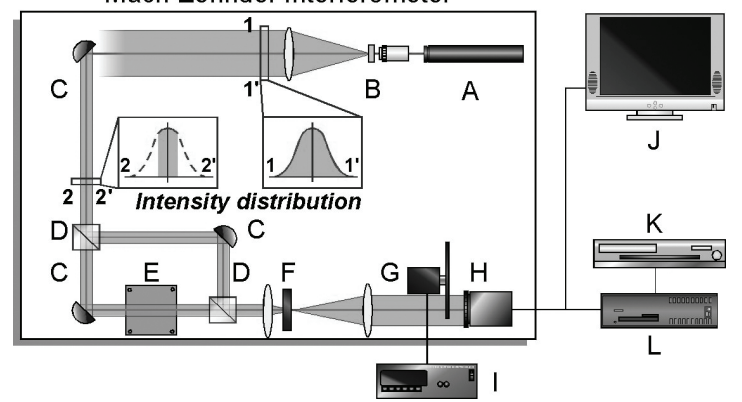

[A] He-Ne laser [B] collimator [C] mirror [D] polarized beam splitter [E] stage for diffusion cell [F] quarter-wave plate $[\mathrm{G}]$ rotating polarizer $[\mathrm{H}] \mathrm{CCD}$ camera $[\mathrm{I}]$ stepping motor controller $[\mathrm{J}]$ monitor for in-situ observation $[\mathrm{K}]$ digital video recorder $[\mathrm{L}]$ image processing unit

Fig. 1 Schematic diagram of experimental set-up.
$\mathrm{CCD}$ センサで異なる3つの干渉縞を取り込み，画像処理 装置（Image Processing Unit :IPU）に転送する方式を採用 した。通常の CCD カメラの直前に回転する偏光板を取り 付け,カメラのサンプリング周期である 1/29.97秒毎に 120 度偏光面を回転させるように回転数を調整した。これに より 3 フレームを 1 つの組み合わせとした干涉縞を得る ことができ，約 $1 / 10$ 秒のサンプリング周期で位相シフト デー夕を取得することが可能となった。これまでの方式 によって得られたデー夕と比べると格段にノイズが低減 し，より高精度に濃度場を可視化できるようになった。 また，視野内のレーザー強度を一様にするため，Fig. 1 内 に示すようにレーザー強度分布中心付近のほぼ一様な強 度領域のみをテストセルに通過させるよう複数枚のレン ズを付加した。これにより装置が固有する視野内の輝度 分布が原因となるかたより誤差(Bias Error)の低減が期待 できる。

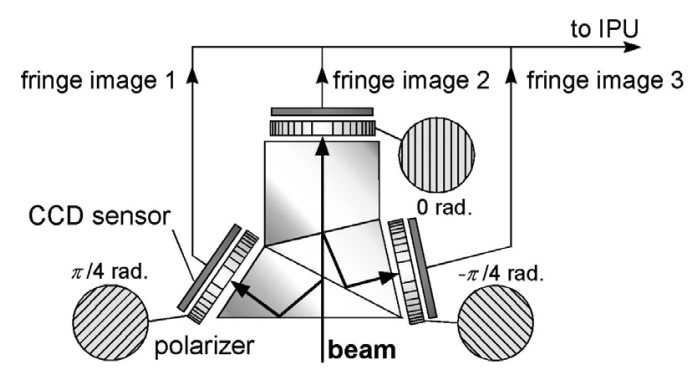

(a) Previous system

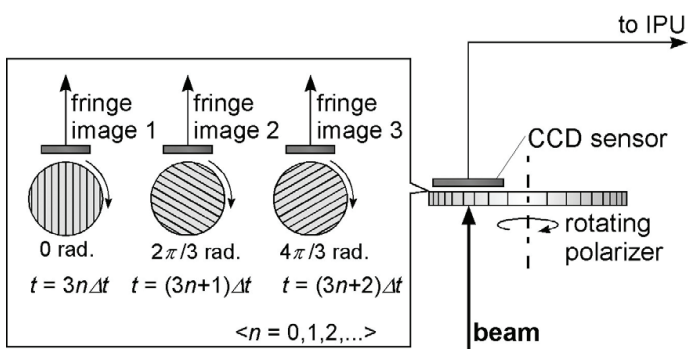

(b) Improved system

Fig. 2 Schematic diagrams of detecting system for phase shifting technique.

\section{2 マイクロ拡散セル}

本研究で使用した極小シェア式拡散セル（マイクロ拡 散セル）を Fig. 3 に示す。試料が注入される観察部分は 光学用石英ガラスで製作し, 熱膨張による光路長の変化

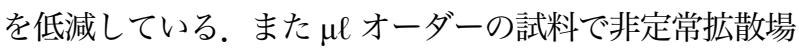
を形成するために，上部・下部の石英ブロックに Fig. 3(b) に示すような $1 \mathrm{~mm} \times 1 \mathrm{~mm} \times 5 \mathrm{~mm}$ の溝を設けた。これによ

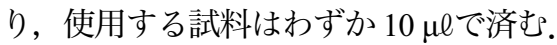


石英セルは Fig. 1 中の E の位置に 5 自由度を有するス テージ上に置かれ，光軸中心が拡散場の中心となるょう に設置される. 拡散場形成時に両ブロックの溝が光軸上 で完全合致するように，石英ブロックのスライド面は広 く設計した。 また，Fig. 3(a)に示すように上部ブロックが 下部ブロック上を平行に移動できるようにテフロン製の ガイドレールを設け，ステッピングモーターによる完全 駆動制御で，滑らか且つずれのない駆動機構を実現した。

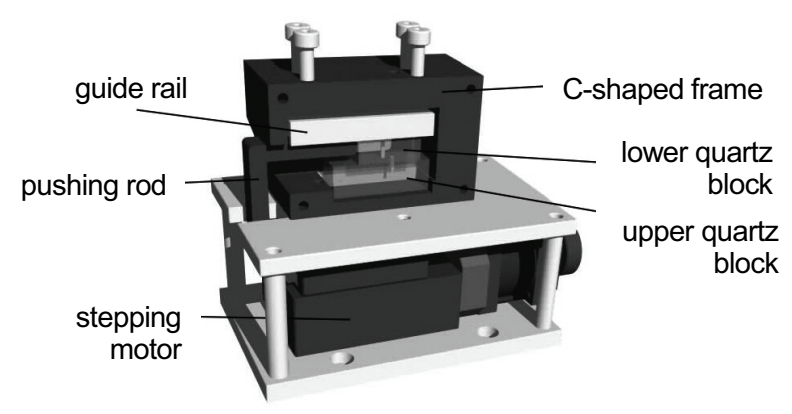

(a) Assembling schematic of micro shearing cell

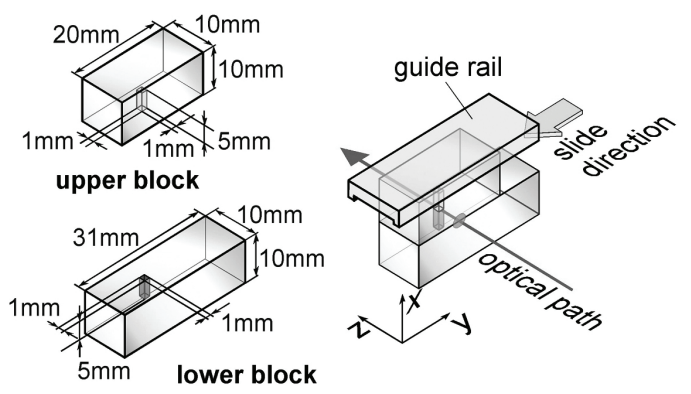

(b) Dimensions of quartz blocks

Fig. 3 Schematics of micro shearing diffusion cell.

\section{3. 解析方法}

位相シフトデータを用いた物質拡散係数の導出法には, Guo ら[10]が導出した方法が挙げられる。この方法を用い ると, 高精度に物質拡散係数を導出できるが, 物質拡散 係数を定数として扱うことができる微小濃度差でのみ適 用可能であるため, 本研究での導出法として取り扱うこ とはできない.したがって，新たな解析方法を適用しな ければならない。

物質拡散係数 $D$ が濃度依存性を有し, 等温一次元の自 由拡散条件下では物質拡散現象は式(1)により記述できる.

$$
\frac{\partial c}{\partial t}=D(c) \frac{\partial^{2} c}{\partial x^{2}}+\frac{\partial D(c)}{\partial c}\left(\frac{\partial c}{\partial x}\right)^{2}
$$
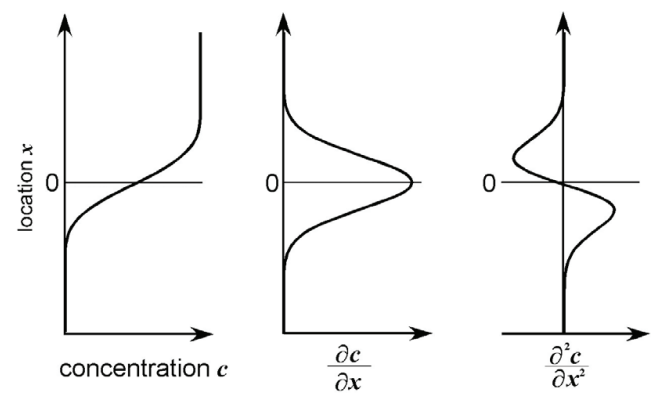

Fig. 4 Distributions of concentration and 1st order, 2nd order derivation values.

ここで $c$ は濃度を， $x, t$ はそれぞれ位置，拡散経過時間 を表す，右辺は二つの項から成り立っており，それぞれ 第一項は濃度勾配の 2 次微分係数，第二項は濃度勾配の 二乗に比例している．右辺各項の影響はそれぞれ拡散場 全空間に及ぶが，局所的な観点では，Fig. 4 より明らかな ように拡散中心付近および両端付近は 2 次微分係数の絶 対值が極小となるため, 相対的に右辺第二項が支配的と なることを示している. 本研究では物質拡散係数の濃度 依存性を定性的に，且つ簡易的に評価するために，以下 の仮定を設けた。

1. 物質拡散係数の絶対值, $D(c)$, に対する濃度依存性, $\partial D(c) / \partial c ， の$ 割合は相対的に小さいものとする.

2. 相対的に右辺第一項が支配的となる領域については, 右辺第二項の影響は無視できるものとする.

3. 本研究で使用する計測系では, 非定常拡散場の初期濃 度分布をほぼステップ状に与えることができ, 且つ拡 散領域幅は分子拡散の自由行程と比べて十分に広い とし, 等温一次元の自由拡散が成り立つ。

以上の仮定から, 局所的濃度勾配の観察が可能な本シ ステムを用いることで, 右辺第一項が支配的となる領域 のみで物質拡散係数の導出を行うこととした，上記仮定 を設けたため, この解析方法で得られた拡散係数を, 本 論文では見かけの拡散係数と記述する。この計測領域内 においては，式(1)の解は局所的に誤差関数を用いて次式 (2)で記述することができる.

$$
c(x, t)=\frac{c_{u}+c_{l}}{2}+\frac{c_{u}-c_{l}}{2} \operatorname{erf}(\xi),
$$

ここで, 添え字 $u, l$ はそれぞれ上部溶液，下部溶液を表 し, 無次元数 $\xi$ は次式(3)で与えられる.

$$
\xi=\frac{x}{2 \sqrt{D(c) t}} .
$$


これらの仮定により, 実験で得られる位置と時刻の組 从合わせ $(x, t)$ において, 式(2)で定義される $\xi$ の值が等 しい組み合わせの集合を同系列とすると, その $\xi の$ 值に対 応する濃度 $c$ の物質拡散係数は, その系列を用いて次式(4) の関係から導出することができる，実験では，㢫等しい ということは輝度値が等しいことに相当するので，同輝 度值を経過時間方向に追従することで, ある $\xi に$ 対する系 列が求められる。

$$
\frac{x^{2}}{4 \xi(c)^{2}}=D(c) \cdot t
$$

式(4)から明らかなように, 左辺の值を時間微分するこ とで見かけの物質拡散係数 $D(c)$ を導出することができ る.この方法により, 一回の測定実験で複数の $\xi$ に関する 系列を作成し, 各濃度における見かけの物質拡散係数を 同時に導出することが可能となる，また，ここから物質 拡散係数の濃度依存性を評価することが可能となる。

\section{4. 実験方法および手順}

\section{1 タンパク質選定と広域緩衝液}

本研究では試料タンパク質として, 比較的入手のしや すい卵白から採取された Lysozyme（通称：ムラミダーゼ Muramidase 分子量 14300）を用いて実験を行った。また タンパク質は一般的に $\mathrm{pH}$ 值の変化に敏感であるため, 種々の $\mathrm{pH}$ 值を有する広域緩衝液に溶解して実験を行っ た。本研究では体内消化器系の極限環境を模擬するため $\mathrm{pH}$ 值を広範囲に設定した，通常，胃の内部は $\mathrm{pH} 1.0 \sim 2.5$ 程度であり，唾液では $\mathrm{pH} 5.5$ 程度，小腸では $\mathrm{pH} 6.0 \sim 7.7$, 胆汁では $\mathrm{pH} 7.6$ ～ 8.6 程度である。そここで緩衝液を強酸か ら弱塩基の範囲に設定した。広域緩衝液として BrittonRobinson 緩衝液を使用し, $\mathrm{pH}$ 值をパラメータとした実験 を行った。

\section{2 実験手順}

測定実験では，物質拡散係数の濃度依存性を評価する ため, 複数種の溶液を必要とする。そこで $\mathrm{pH}$ 值の異なる 広域緩衝液に Lysozyme を溶解し， $0.0,50.0,100.0 \mathrm{mg} / \mathrm{ml}$ の濃度を有する試料溶液を作成した。これらを Table 1 に 示した組み合わせにすることで非定常濃度拡散場を形成 した。低濃度溶液を上部に，高濃度溶液を下部に注入す ることで浮力の影響を抑え安定層を形成し，石英セルの
Table 1 Summary of Experimental Conditions

\begin{tabular}{cccc}
\hline Exp. Run No. & $\mathrm{pH}$ & $\begin{array}{c}\text { upper conc. } \\
\mathrm{mg} / \mathrm{ml}\end{array}$ & $\begin{array}{c}\text { lower conc. } \\
\mathrm{mg} / \mathrm{ml}\end{array}$ \\
\hline 1 & 4.29 & 0.0 & 50.0 \\
2 & 4.29 & 50.0 & 100.0 \\
3 & 6.23 & 0.0 & 50.0 \\
4 & 7.06 & 0.0 & 50.0 \\
5 & 8.44 & 0.0 & 50.0 \\
6 & 8.44 & 50.0 & 100.0 \\
\hline
\end{tabular}

中心点に光軸が通過するよう光学系に設置し実験を行う こととした．測定実験は $25^{\circ} \mathrm{C} に$ 保たれた恒温室で行い， 偶然誤差低減のため同一条件で複数回の実験を行った。 拡散場を形成する上下溶液の濃度差は全ての実験におい て, $\Delta c=50.0 \mathrm{mg} / \mathrm{ml}$ とした.

また, Fig. 3 に示す上部石英ブロックは, 初期擾乱の影 響を低減させるために，擾乱が最小となる速度（せん断 速度）で移動させなければならない，速い速度でスライ ドさせると溶液内に強い渦流れが生じてしまう。逆に遅 い速度では上下セルの不完全合致による二次元拡散が進

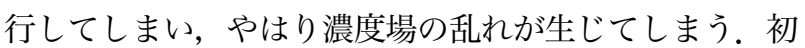
期渦流れは溶液合致後, 上下セル内の流れ方向が互いに 打ち消す方向であるため, 直ちに流れ場は消滅し安定す るが，その流れの減衰速度および不完全合致による濃度 場の乱れの一次元性回復は試料溶液の動粘度 $v$, および物 質拡散係数 $D$, に大きく依存することが容易に推測でき る. 今回の実験では, Britton- Robinson 緩衝液の動粘度が 水に近い值であること，およびタンパク質の物質拡散係 数が無機塩のそれより小さく推定されることから, 動粘 度が支配的であると考えられるため，せん断速度を 0.5 $\mathrm{mm} / \mathrm{s}$ 以下で実験を行うことにした。

\section{5. 実験結果および考察}

5.1 位相シフトデータと非定常拡散場

前述した手順に従って実験を行い，位相シフトデータ によって可視化した非定常拡散場を Fig. 5 に示す. Fig. 5(a) は，拡散開始直後の非定常拡散場の様子を表している. 図から明らかなように，上下溶液の合致直後は一次元拡 散を呈していない拡散場が観察されたが，それは直ちに 解消され，その後は大きな擾乱もなく一次元性を保ちな がら拡散が進行していく様子が確認された。これはせん 断速度が妥当であったことを示している．また，Fig. 5(b) に示すように, 幅 $1 \mathrm{~mm}$ の拡散チャネル内では壁の影響を 受けることなく一次元拡散が進行していく様子が観察さ れ，解析方法にて仮定をした 3 の条件を満たしているこ 


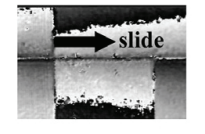

$t=0.00 \mathrm{~s}$

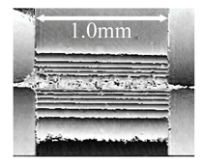

$t=60 \mathrm{~s}$

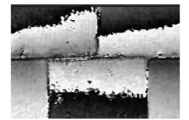

$t=0.25 \mathrm{~s}$

(a)

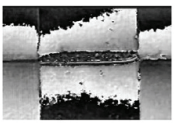

$t=0.50 \mathrm{~s}$

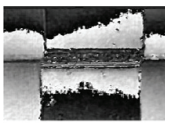

$t=1.00 \mathrm{~s}$

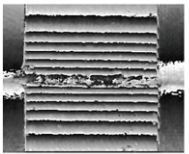

$t=300 \mathrm{~s}$

(b)

Fig. 5 Snapshots of transient diffusion field visualized by phase shifted data

とが確認された。

これらの位相シフトデータから非定常濃度分布を導出 するのだが, Fig. 6(a) に示す位相シフトデータによって可 視化された非定常拡散場は，濃度場の情報が空間的に連 続な輝度值で与えられ，この情報から最大輝度と最小輝 度を256分割(8bit) したデジタルデータとして Fig. 6(b) に 示すような輝度值分布を得ることができる。これらの值 は上記輝度值範囲内で定義づけられているので，輝度值 が急変する点で輝度值 255 を加算して接続すれば, Fig. 6(c) に示すような連続輝度分布を得ることができる．こ の輝度分布は濃度分布を示しており, 画像 1 ピクセルに 相当する空間解像度 $0.017 \mathrm{~mm}$ の濃度分布を高精度に取得 することが可能となる。 また，Fig. 6(a)における位相シフ トデータの上下両端の濃度が既知（ここでは $\Delta c=50.0$ $\mathrm{mg} / \mathrm{ml}$ になる) であるため, 屈折率の濃度依存性が濃度に 対し線形である場合，各ピクセルは濃度の絶対值を有す ることになる。

この方法を用いると, 拡散場進行方向と垂直な方向に 存在するピクセル数の系列分の濃度分布を取得できるこ とになる。つまり一回の測定で複数のデー夕取得が可能 となり，結果として局所的に生じる時間的空間的誤差要 因による測定の誤差を低減できるようになる。 さらに， セルガラスの污れやセル製作時における局所的ひずみ等 の装置固有の偏り誤差については，その系列を排除する ことで，更なる䛊差要因の低減に繋げることができる.

\section{2 見かけの物質拡散係数導出および周囲環境の影} 響評価

はじめに, Fig. 6(c) に示した輝度分布導出法により得ら れた pH8.44（Table 1 内実験 No. 5) における非定常拡散場 の濃度分布を Fig. 7 に示す. 得られた分布は原点に対して 点対称分布を呈しているが，拡散初期段階ではその分布 に偏りを有していることがわかる.特に $t=300 \mathrm{~s}$ における

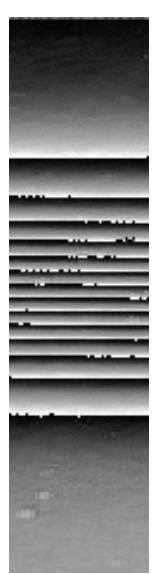

(a)

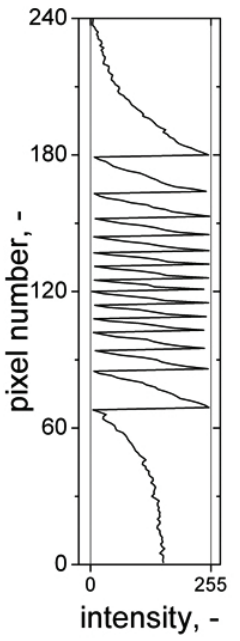

(b)

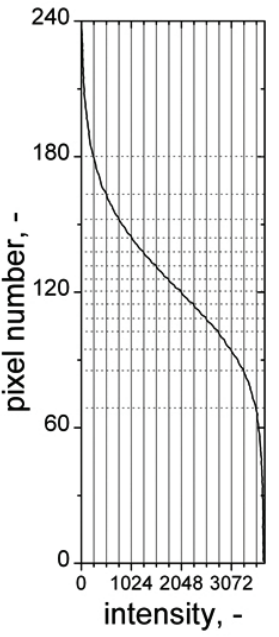

(c)
Fig. 6 Results of visualization of diffusion field. (a) diffusion field visualized by phase shifted data; (b) intensity distribution of phase shifted data; (c) connected phase shifted data

分布では低濃度領域において濃度分布の拡がりが高濃度 領域よりも進行している様子が Fig. 7 より分かる.このこ とは拡散係数が低濃度側領域で大きな值をとり，局所濃 度に依存していることを意味している。この傾向は拡散 開始後短時間以内ではなく, 拡散進行後も低濃度領域で は拡がりが速い結果が得られた。

この依存性を定量的に評価するために，前述した解析 方法を用いて見かけの物質拡散係数の導出を試みた. Fig. 7 に対応して, 実験 No. 5 の結果から得られた式(4)の関係 を Fig. 8 に示す。物質拡散係数が濃度に依存しなければ, Fig. 8 内の全ての点は同一線上に集約することになるが, 実験結果では各濃度において独自の直線を形成した。こ れは物質拡散係数が濃度依存性を有しているためであり, この直線の傾きから物質拡散係数の濃度依存性を評価す ることができる，各濃度において，最小二乗法で得られ た直線の傾きから導出された見かけの物質拡散係数を Fig. 9 に示す. 物質拡散係数の導出の際には，装置のかたより

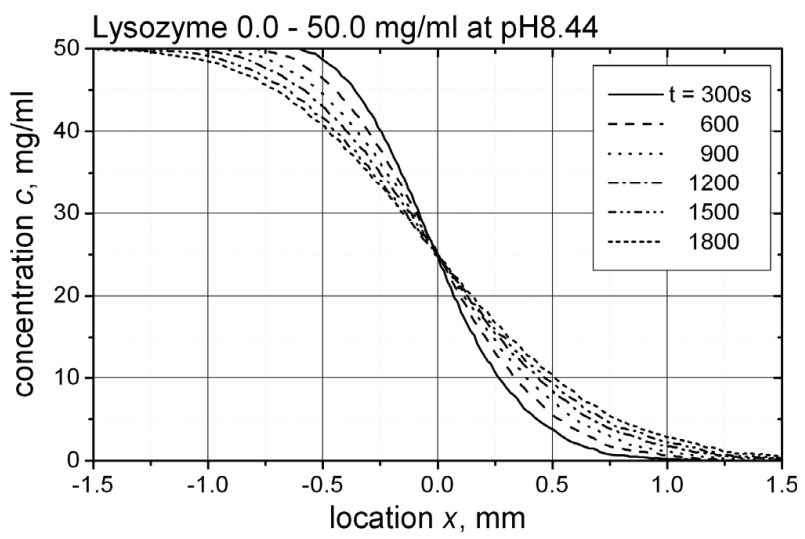

Fig. 7 Concentration distribution of diffusion field 


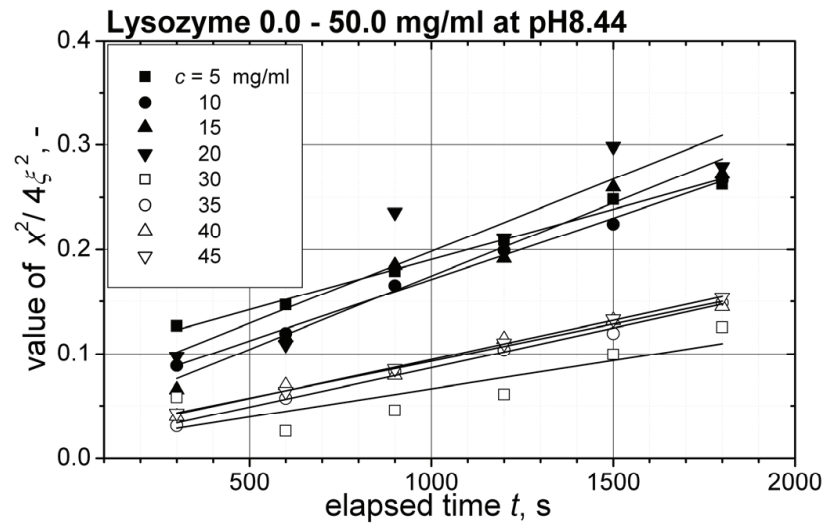

Fig. 8 Relationship between elapsed time and the value of $x^{2} / 4 \xi^{2}$.

誤差および測定時の偶然誤差を考慮して不確かさ評価を 行い, 95\%包括度で評価した值を図中にエラーバーで表記 してある. Fig. 9 より明らかなことは，第一に Fig. 7 およ び Fig. 8 で示した濃度依存傾向は, pH8.44の場合のみに 特化される傾向であるということである. 他の $\mathrm{pH}$ 条件下， 特に酸に偏ると高濃度領域で物質拡散が促進される傾向 がみられる。このように物質拡散係数はどの $\mathrm{pH}$ 值におい ても濃度依存性を有していることが分かり，ただしその 傾向は $\mathrm{pH}$ 值つまりは周囲環境によって異なり, その関係 はほぼ線形的であることが示唆された。また，周囲環境 が強酸に偏ると，どの濃度領域においても，拡散現象が 促進され見かけの物質拡散係数が大きくなる傾向がある ことが明らかになった。このメカニズム解明については 現在検討中である. 以上より, タンパク質は体内等の極 限環境下では濃度依存性を有する他, $\mathrm{pH}$ 值の周囲環境に 大きく依存した拡散現象を呈することが確認された。

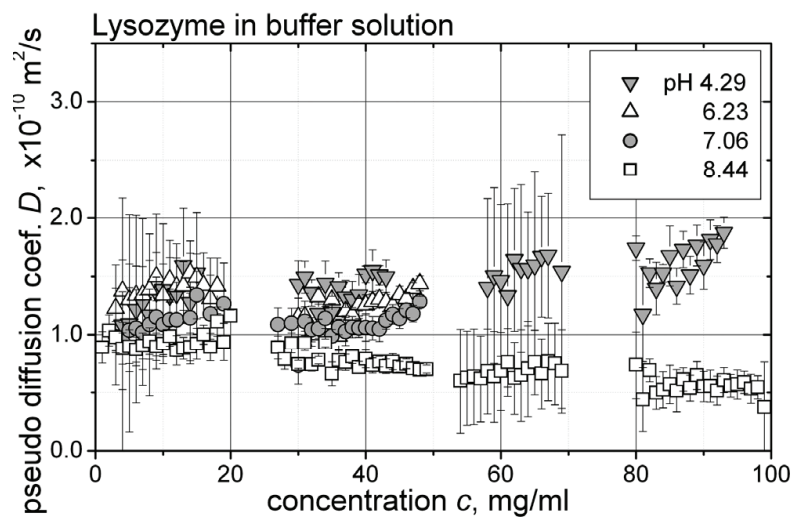

Fig. 9 Concentration and $\mathrm{pH}$ value dependencies of the mass diffusion coefficient.

\section{6. 結言}

本研究では, タンパク質 Lysozyme の極小非定常拡散場 を可視化することで，見かけの物質拡散係数を導出した．
以下に本研究で得られた知見を示す.

(1) 従来の位相シフト干渉計に改良を施し, 濃度分布の空 間的連続デー夕を高解像度取得することで, より鮮明 且つ高精度に極小非定常拡散場を観察可能にした。

（2）広域緩衝液の $\mathrm{pH}$ 值をパラメータとした実験を行い, 物質拡散係数が $\mathrm{pH}$ 值に大きく依存することを明らか にした. 周囲環境が強酸に偏ると見かけの物質拡散係 数はどの濃度領域においても増大し, 拡散現象が促進 されることを確認した。

(3) 各 $\mathrm{pH}$ 值において, 広範囲濃度における Lysozyme の 見かけの物質拡散係数を導出し, 濃度依存性を定性的 に評価した.この依存性はほぼ線形的な関係を有して いるが，その傾向は $\mathrm{pH}$ 值つまりは周囲環境によって 異なることを示した。

\section{NOMENCLATURE}

c. : concentration, $\mathrm{mg} / \mathrm{ml}$

$D$ : diffusion coefficient, $\mathrm{m}^{2} / \mathrm{s}$

$t$ : elapsed time, $\mathrm{s}$

$x \quad$ : location, $\mathrm{m}$

$\xi \quad$ : dimensionless symbol, -

Subscript

$l \quad:$ lower

$u$ : upper

\section{参考文献}

[1] V. Magueijo, V. Semiao, M.N. Pinho; Int. J. Heat Mass Transf., 48(2005), 1716-1726.

[2] T. Varzakas, I. Escudero, I.G. Economou; J. Biotechnol., 72(1999), 77-83.

[3] C. Mattisson, P. Roger, B. Jönsson, A. Axelsson, G. Zacchi; J. Chromatogr. B, 743(2000), 151-167.

[4] J. Gutenwik, B. Nilsson, A. Axelsson; Biochem. Eng. J., 19(2004), 1-7.

[5] S. Liang, J. Xu, L. Weng, H. dai, X. Zhang, L. Zhang; J. Control. Release, 115(2006), 189-196.

[6] A. Komiya, S. Maruyama; Exp. Therm. Fluid Sci., 30(2006), 535-543.

[7] A. Komiya, S. Maruyama, S. Sakai, K. Tsukamoto; Proc. 2nd Pan-Pacific Basin Workshop on Microgravity Sci., (2001), CD-ROM TP-1121.

[8] 小宮敦樹、円山重直、守谷修一; 第 25 回日本熱物 性シンポジウム講演論文集、(2004), 342-244.

[9] S. Nakadate, M. Isshiki; Proc. Photo. Instrum. Eng., 2544(1995), 74.

[10] Z. Guo, S. Maruyama, A. Komiya; J. Phys. D: Appl. Phys., 32(1999), 995-999.

[Received Sep. 29, 2009, Accepted Jan. 12, 2010] 